\title{
EESTI AJALOOTEADUSE UUED SUUNAD 21. SAJANDIL
}

\author{
Linda KALJUNDI ${ }^{\mathrm{a}}$ ja Aro VELMET ${ }^{\mathrm{b}}$
}

\begin{abstract}
${ }^{a}$ Eesti Kunstiakadeemia, kunstikultuuri teaduskond, kunstiteaduse ja visuaalkultuuri instituut, Põhja pst 7, Tallinn 10412, linda.kaljundi@artun.ee

b Lõuna-California Ülikool, Dornsife College of Arts and Sciences, ajaloo osakond, 3502 Trousdale Parkway, Los Angeles, CA 90089, velmet@usc.edu

Artikkel annab ülevaate Eesti ajalooteaduse uutest uurimissuundadest, keskendudes rahvusülesele ajaloole, mälu-uuringutele ning teadus- ja keskkonnaajaloole. Need valdkonnad võimaldavad ühelt poolt tõsta fookusesse seni marginaliseeritud ühiskonnagruppe ja tegutsejaid, teisalt toovad need esile ajalooteaduse olemusliku poliitilisuse. Käsitledes ajalooteaduse kõrval ka teisi humanitaarteadusi, rõhutame vajadust võtta tõsiselt ajaloolise materjali käsitlemist kõrvaldistsipliinides. Väidame, et Eesti ajalooteaduses on tugevalt esindatud kultuuriliste representatsioonide uurimine, mida saaks senisest ulatuslikumalt ühendada sotsiaal- ja majandusajalooga ning võimusuhete uurimisega.
\end{abstract}

Ülevaadet Eesti ajalooteaduse arengujoontest uuel aastatuhandel võib kirjutada väga mitut moodi, kuid raske on vältida veel üht progressivaimus lugu teaduse kõige moodsamate suundadega kaasaskäimisest. Siiski püüab järgnev ülevaade vaadelda sellist uurimistööd, mis problematiseerib ja arendab käsitlusviise ka ise edasi ning püüab ühtlasi muuta siinses ajalooteaduses käibivaid arusaamu ja hierarhiaid. Humanitaarteaduste arengut on viimasel ajal kirjeldatud pöörete ja rändavate mõistete kaudu ning alanud aastatuhandel on uurimissuundi ja märksõnu esile kerkinud üha rohkem ja kiiremini. Siinne arutelu on üles ehitatud nelja suuna ümber: rahvusülesus, mälu ning teadus- ja keskkonnaajalugu. Kahtlemata ei ammenda me sellega kaugeltki kõiki Eesti ajalooteaduses hiljuti esile kerkinud suundumusi, vaid rääkida võiks veel paljudest pööretest ja käänetest. Keskendume just nendele suundumustele, sest leiame, et nende kaudu avaldub hästi ajalooteaduse dialoog teiste distsipliinidega ja samuti ühiskonnaga. Nagu teisteski valdkondades, nii on ka ajalooteaduses palju viljakaid uurimisprobleeme sündinud eri distsipliinide piirialadel. Soovime ühtlasi osutada, kui olulisel määral tegeletakse Eestit puudutava ajaloolise uurimistööga ka väljaspool traditsiooniliselt ajaloo alla kuuluvaid distsipliine ning et seda uurimistööd on vaja võtta tõsiselt. Sellepärast on artiklisse olulisel mää- 
ral kaasatud ka teistes humanitaarteadustes sündinud uurimusi. See ei anna häält mitte ainult teistsugustele distsiplinaarsetele vaatenurkadele, vaid võib suurendada ka ajaloolises uurimistöös avalduvat mitmehäälsust.

Mitmehäälsuse esiletoomine on tihedalt seotud ka ajalooteaduse ja ühiskonna suhetega, mida järgnevalt samuti vaatleme. Keskendume seejuures 21. sajandi ajalookirjutuse suhestumisele võimusuhete analüüsiga, mida näeme ühtaegu hiljutiste uuringute põhilise saavutuse, aga ka täitmata potentsiaalina. Seda kahel tasandil. Esiteks tuleks uute sfääride, inimgruppide ja probleemide liikumist uurijate fookusesse mõtestada kui poliitilist akti, mis võib muuta nähtavaks vaikimisi eiratud, hääletud ja marginaliseeritud ühiskonnagrupid, olgu selleks siis vähemusrahvused poliitilises ajaloos või mitteinimesed keskkonnaajaloos. Eesti humanitaarteadusi viimasel ajal palju mõjutanud filosoof Jacques Rancière on seda protsessi, mille käigus seatakse kahtluse alla reeglid, mille põhjal „nähtavaid“ ja „nähtamatuid“ ühiskonnaliikmeid liigitatakse, nimetanud „tajutava jaotuskorra“ ümberjaotamiseks. ${ }^{1}$ Kuivõrd uued ajaloovoolud just ümberjaotamisega tegelevad, on siin tegu poliitilise aktiga, mida tuleks käsitleda refleksiivselt, küsides, kui palju on uued uurimissuunad Eesti ajaloo subjektide ringi laiendanud; aga ka seda, millised grupid ja probleemid on jäänud hääletuks. Toome välja Eesti ajalookirjutuse „nähtavaid“ subjekte suures osas jätkuvalt defineeriva rahvusliku ajalookirjutuse piirid ning näitame, kuidas uued uurimissuunad neid ületada üritavad.

Teiseks arutleme selle üle, kuivõrd on uute raamistike (nt rahvusülese või keskkonnaajaloo) kasutuselevõtt aidanud ajaloolastel välja töötada tööriistu ajalooliste võimusuhete, hierarhiate, tahte kehtestamise viiside täpsemaks analüüsiks. Paljud uued, rohkemal või vähemal määral kultuurilisest pöördest mõjutatud uuringud on toonud hästi esile Eesti ajaloole ja kultuurile omase hübriidsuse. Semiootikast ja postkoloniaalsest teooriast laenatud hübriidsuse mõistet on kasutanud ajaloolased ja veelgi enam kultuuriteadlased. See aitab ületada, eriti rahvuslikus ajalookirjutuses, tavapäraseid vastandusi eestlaste ja „teiste“, anastajate ja ohvrite, tsivilisatsiooni ja looduse vahel. Siiski ilmnevad neis uuringutes ka hübriidsuse kui tööriista piirid, sageli jääb tähelepanu alt välja seotud gruppide või diskursuste hierarhiseerituse, vastuolulisuse ja vägivalla roll.

Piiratud mahu tõttu ei saa siinne sissevaade kuidagi võtta eesmärgiks kajastada kõiki uusi ilminguid Eesti ajalooteaduses ja sellega põimuvates distsipliinides. Samuti tekitas palju küsimusi teemanumbri lähteülesanne: keskenduda Eesti päritolu ja/või Eesti institutsioonidega seotud ajaloolastele. Kes on õige Eesti ajaloolane, kes on ülepea õige ajaloolane? Kuidas neid termineid defineerida, kui Eesti ajaloo mõistmisesse uuendusi toonud uurimistööd iseloomustab rahvusvaheline põimitus, koostöö mitte-Eesti ajaloolastega ning interdistsiplinaarne koostöö mitte-ajaloolastega? Ka siin leiame, et osutades viisidele, kuidas ajalooteadus võiks üritada rahvuslikku tajutavat jaotuskorda ületada, oleks silmakirjalik samas distsiplinaarset tajutavat jaotuskorda taaskehtestada. Sestap oleme oma ülevaatesse haaranud eklektiliselt teadlasi, kes on rahvusülesuse, mälu, teadusmõtte ja keskkonnaküsimusi

1 Vt Rancière, J. Esteetika kui poliitika: Valik esseid. Tlk A. Saar. Eesti Kunstiakadeemia Kirjastus, Tallinn, 2017. 
ajalooliselt vaadelnud, sõltumata sellest, kas nad defineerivad end ajaloolase, kirjandusteadlase, semiootiku või kellegi muuna. Omaette teema on uue uurimisvälja tekke määratlemine - kas see toimub ennekõike probleemipüstituste ja programmide või uurimuste ja monograafiate kaudu? Siin avaldub Eesti teadusbürokraatia eripära: monograafiaid on vähe, artikleid palju. Mitmed uued teemad on Eestis sisse töötatud üleskutsete ja ülevaateartiklite kaudu, samuti on oluline roll olnud mittekirjalikel formaatidel - ettekannetel ja üritustel, mille korraldamist Euroopa Liidu struktuurifondide raha on viimasel kümnendil heldelt toetanud. Suve- ja talvekoolidele ning tippkeskustele toetuv rahastussüsteem on küll aidanud siinset teaduselu mitmekesistada ja luua võimalusi oma valdkonna välisekspertidega mõtteid vahetada, ent see pole loonud tingimusi pikaajaliste uuringute korraldamiseks, mis uute suundade ülesehitamist pikemas perspektiivis toetaksid.

\section{RAHVUSLIK AJALUGU JA TEMA TEISED - RAHVUSÜLENE, PÕIMITUD JA KOLONIAALAJALUGU}

Eesti ajalookirjutuses vaikimisi domineeriv „tajutav jaotuskord“, ajaloo vaatevälja haaratud teemadering, on ka 21. sajandil olnud jätkuvalt rahvuslik. Et rahvuslikkuse küsimus pole Eesti ajalookirjutuses kaugeltki selgeks vaieldud, sellest annavad märku jätkuvad debatid - tuntuim neist 2013. aasta alguses Eesti ajaloo keskaja-köite ${ }^{2}$ ümber toimunud tuline arutelu. 2020. aastaks ei ole vaidlused ega ka rahvuslik ajalugu kuskile kadunud - see on siiani valdav paljudes õpikutes, muuseumides, populaarsetes üldkäsitlustes jm. ${ }^{3}$ Rahvusluse tagasitulek on globaalne fenomen, kuid Eestis (nagu mujalgi Ida-Euroopas) on vahepealne dekonstrueeriv kihistus hõre. Läbi on uurimata ja vaidlemata suured kategooriad - nagu „klass“, ,sugu“, „rass“ ning mõistagi „rahvus“ ise -, mida Läänes hiljemalt 1980-ndatel kriitilise teooria läbimurde raames käsitleti.

Rahvuse kujunemise ajaloost hiljutisi mahukamaid ülevaateid ei ole, kuigi uusi teoreetilisi perspektiive ja võimalusi on käsitletud. ${ }^{4}$ Olulisimaks autoriks on jätkuvalt Ea Jansen, kelle suuremad tööd puudutavad rahvuslike aktivistide ja võrgustike ajalugu. ${ }^{5}$ Rahvusliku ideoloogia ja identiteedi kujunemist on vaagitud pigem üksikute teemade kaupa,${ }^{6}$ samuti on fookus püsinud rahvusluse ja rahvusriigi loomise ajas ehk 19. sajandis ja 20. sajandi alguses. Sealhulgas on põhjalikumalt läbi kirju-

2 Eesti ajalugu II: Eesti keskaeg. Toim A. Selart. Tartu Ülikooli ajaloo ja arheoloogia instituut, Tartu, 2012.

3 Nt Tarvel, E. Eesti rahva lugu. Varrak, Tallinn, 2018.

4 Raun, T. Nineteenth- and early twentieth-century Estonian nationalism revisited. - Nations and Nationalism, 2003, 9, 129-147; Piirimäe, E. Teoreetilisi perspektiive 19. sajandi eesti rahvuslusele. - Vene impeerium ja Baltikum: Venestus, rahvuslus ja moderniseerimine 19. sajandi teisel poolel ja 20. sajandi alguses. Toim T. Tannberg, B. Woodworth. (Eesti Ajalooarhiivi toimetised, 16 (23).) Eesti Ajalooarhiiv, Tartu, 2009, 167-191.

5 Jansen, E. Eestlane muutuvas ajas: Seisuseühiskonnast kodanikuühiskonnani. Eesti Ajalooarhiiv, Tartu, 2007.

${ }^{6}$ Nt Põhjamaadega seotud võrgustikud ja identiteedid. Kuldkepp, M. The Scandinavian connection in early Estonian nationalism. - Journal of Baltic Studies, 2013, 44, 313-338. 
tamata ka ajalookirjutuse ajalugu ja roll rahvuse kujunemisel. ${ }^{7}$ Praeguseks tegeletakse rahvusliku ajalookirjutusega üha enam rahvusülesest perspektiivist ja mõne võrdleva projekti raames on jõutud käsitleda ka Eestit. ${ }^{8}$ Eestis endas on sellega viimasel ajal tegeletud rohkem mälu-uuringute raames, keskendudes paljuski rahvusromantiliste motiivide ja narratiivide sünniloole (vt tagapool). Selle kõrval oleks sama vajalik välja selgitada seegi, kui paljud neist elementidest arenesid edasi, teisenesid ja võimendusid ajalookirjutuses (aga ka laiemalt kultuurimälus) just nõukogude ajal. Sellised käsitlused saavad kaasa rääkida rahvusvahelises uurimistöös, mis puudutab Nõukogude võimu suhteid rahvuslikkusega. Et see on võimalik, on näidanud Nõukogude Eesti kunstiajalookirjutuse võrdlev analüüs. ${ }^{9}$

Vaatame järgnevalt käsitlusi, mis on otsinud rahvuslikule vaatenurga alternatiivi: rahvusülest ajalugu (transnational history) ning sellega Eestis tihedalt seotud põimitud ajaloo (entangled history) ja kolonialismi uuringuid. Need suunad on rahvusvaheliselt sageli tihedalt seotud ja veel enam võib seda väita Eesti kohta, kus kohaliku ajaloo ja kultuuri rahvusüleste käsitluste autorid on tihti olnud huvitatud ka põimitud ajaloost ja kolonialismist. ${ }^{10}$ See on seotud katsetega otsida siinse mitmerahvuselise maa ajaloo, ühiskonna ja kultuuri käsitlemiseks sobivat teoreetilist raamistikku. Et sellega on palju tegelenud kirjandusteadlased, siis on just selles valdkonnas arenenud üks ajaloo- ja kultuuriteaduste viljakamaid dialooge.

Ehkki Eestis ei ole rahvusülese ajaloo märksõna laiemalt juurdunud, siis taanduvad ka eelmainitud ajaloovaidlused just küsimusele, kas kirjutada rahvuslikku või rahvusülest ajalugu. Nende terminite asemel on ajaloolaste seas siiani laialdaselt käibel 2013. aastal keskaja köite vaidluste käigus lendu läinud metafoor: konna ja kure perspektiiv. Loomametafoor toob meelde rea õpetlikke valme, kuid siiski tasuks rääkida probleemist otse - sisuliselt on tegemist valikuga rahvusriigi perspektiivist või rahvusüleselt kirjutatud ajaloo vahel (kas „muistne vabadusvõitlus“ on osa Eesti võitlusest omariikluse eest või osa kristliku Euroopa ekspansiooni ajaloost?). Just rahvusülest perspektiivi Eesti keskajale see köide ka pakkus, keskendudes eestlastest talurahva kõrval mitmesugustele teistele toimijatele ja võrgustikele, isegi kui lähenemisviis polnud otseselt rahvusülese ajaloona raamistatud.

Rahvusülese ajaloo raames on analüüsitud inimeste, ideede, tehnoloogiate jm piirülest levikut, kultuuride ja identiteetide hübriidsust. Seda seob ühelt poolt soov

\footnotetext{
7 Selart, A. Eestlaste oma ajalooteadus. - Keel ja Kirjandus, 2018, 1-2, 41-49.

8 Nt projekti „Representations of the past: The writing of national histories in nineteenth and twentieth century Europe“ (2003-2008) väljannetes; Hackmann, J. Narrating the building of a small nation: Divergence and convergence in the historiography of the Estonian „,national awakening“, 1868 2005. - Nationalizing the past: Historians as nation builders in modern Europe. Ed. by S. Berger, C. Lorenz. Palgrave Macmillan, Basingstoke, 2010, 170-191. Vt ka Tamm, M. Euroopa rahvuslik ajalookirjutus võrdlevas vaatluses. - Tuna, 2017, 2, lk 128-138. Selle projektiga seotud ideedest on kantud ka väitekiri: Kukk, K. Väikerahvuste ajalookäsitluste genees ja narratiivid: Eesti võrdluses teiste Põhjala ja Baltikumi mittedominantsete rahvustega 19. sajandist kuni Teise maailmasõjani. Tartu Ülikooli Kirjastus, Tartu, 2013.

9 A socialist realist history? Writing art history in the post-war decades. Ed. by K. Kodres, K. Jõekalda, M. Marek. Böhlau, Köln etc., 2019.

${ }^{10}$ Kaljundi, L., Plath, U. Eesti ajalookirjutus põimitud perspektiivist. - Tuna, 2017, 1, 2-6.
} 
otsida alternatiive rahvusriigi vaatenurgast kirjutatud ajalugudele, teisalt soov mõista rahvust ja rahvusriiki kui seletust nõudvat ajaloolist küsimust, mitte kui enesestmõistetavat antust, mille raamidesse ajalookirjutus peab mahtuma. Üsna sarnaselt positsioonilt lähtuvad ka põimitud ja globaalne ajalugu. Seega toob rahvusülene perspektiiv ajaloolaste vaatevälja terve hulga uusi inimgruppe, kelle kogemust rahvusriigi kujunemise seisukohast vaadatuna seni pole fookusesse asetatud. ${ }^{11}$ Eesti ajaloos on objektide ja subjektide ringi laiendamise potentsiaal suur - siinse mitmerahvuselise maa ajalugu on olnud pikk, suhted võimukeskustega muutlikud ja keerulised. Seeläbi on Eesti ajalooteadusel head eeldused rääkida kaasa rahvusülese ajaloo mõtestamises laiemalt. Praeguseks on laiemasse ja rahvusvahelisemasse aruteluringi jõudnud käsitlused baltlaste toimimisest Vene paljurahvuselises impeeriumis - see on teema, millest on 2010. aastatel räägitud küllalt palju seoses nn imperiaalse pöördega. ${ }^{12}$ Imperiaalse dimensiooni sissetoomine on võimaldanud mõtestada uuel viisil ka siinse ühiskonna toimimist ja võimusuhteid. Kõige ilmekamaks näiteks on selle raames sündinud uus arusaam venestamisest. Imperiaalse ja rahvusülese ajaloo konteksti paigutatuna on Eesti rahvuslikus ajaloos oluline mõiste osutunud problemaatiliseks ning uurijad on rõhutanud, et keisririigi rahvuspoliitika oli pigem reaktiivne, bürokraatlike ja moderniseerivate reformide tagajärg ega järginud mingeid läbimõeldud assimileerivaid kontseptsioone. ${ }^{13}$ Rahvusüleses ja imperiaalses kontekstis on Eesti ajalugu analüüsinud ka teadusajaloolased; samuti pakub metodoloogilisest natsionalismist loobumiseks palju võimalusi keskkonnaajalugu (vt edaspidi).

Pikemas ajalises vaates on rahvus- ja kultuuriüleselt seisukohalt Eesti ainest uuritud ka siinse regiooni seltside, ühenduste ja võrgustike ajalooga seoses. ${ }^{14}$ Samuti on analüüsitud järjepidevust Vene impeeriumi ja Nõukogude Liidu kui paljurahvuseliste riikide vahel, aga ka NSV Liidu ja iseseisvuse taastanud Eesti vahel. ${ }^{15}$ Võib

${ }^{11}$ Kaljundi, L. Mis on rahvusülene ajalugu? Intervjuu Karsten Brüggemanni ja Ulrike Plathiga. Sirp, 19.08.2016.

${ }^{12}$ Vt Woodworth, B. D., Tannberg, T. „Imperiaalne pööre“ paljurahvuselise Vene impeeriumi uurimisel. - Vene impeerium ja Baltikum: Venestus, rahvuslus ja moderniseerimine 19. sajandi teisel poolel ja 20. sajandi alguses II. Toim T. Tannberg, B. D. Woodworth. (Eesti Ajalooarhiivi toimetised, 18 (25).) Eesti Ajalooarhiiv, Tartu, 2010, 5-15; Woodworth, B. D. Civil society and nationality in the multiethnic Russian Empire: Tallinn/Reval, 1860-1914. Ph. D. dissertation. Indiana University, Bloomington, 2003; Brüggemann, K. Licht und Luft des Imperiums: Legitimations- und Repräsentationsstrategien russischer Herrschaft in den Ostseeprovinzen im 19. und frühen 20. Jahrhundert. Harrassowitz, Wiesbaden, 2018; Karjahärm, T. Vene impeerium ja rahvuslus: Moderniseerimise strateegiad. Argo, Tallinn, 2012.

${ }^{13}$ Brüggemann, K. Lõpp venestusele: Ühe vaieldava uurimisparadigma kriitika. - Vene impeerium ja Baltikum, 360-374.

${ }^{14}$ Vereinskultur und Zivilgesellschaft in Nordosteuropa: Regionale Spezifik und europäische Zusammenhänge. Hrsg. v. J. Hackmann. (Quellen und Studien zur baltischen Geschichte, 20.) Böhlau, Wien, 2012.

${ }^{15}$ Võistlevad õnned - elukeskkond külma sõja perioodil = Constructed happiness - domestic environment in the cold war era. Toim M. Kalm, I. Ruudi. Eesti Kunstiakadeemia, Tallinn, 2005; Russland an der Ostsee: Imperiale Strategien der Macht und kulturelle Wahrnehmungsmuster (16. bis 20. Jahrhundert). Hrsg. v. K. Brüggemann, B. D. Woodworth. Böhlau, Köln, 2012. 
eeldada, et rahvusülene perspektiiv mõjutab oluliselt just nõukogude aja käsitlemist. Kui seni on rahvuslik ajalookirjutus Nõukogude Liidu ajaloo uurimisel keskendunud repressioonidele, autoritaarsele riigikorrale ja dissidentlusele, siis nüüd näikse tähelepanu järjest enam koonduvat argielu, turismi jms ümber, mida on rahvusülese ajaloo raames käsitletud rohkelt ka mujal. ${ }^{16}$ Samuti on nõukogude aja lõpu uurimisel rõhuasetus massiliikumistelt ja murrangulisuselt nihkunud hoopis mitmesuguste intellektuaalsete ja sotsiaalsete kogukondade järjepidevusele ja kohanemisele. Siin on tähelepanu leidnud eriti Eesti ala mõttelugu ja kolhoosisüsteemi-maaelu sotsiaalne ajalugu. ${ }^{17}$

Viimasel ajal on rahvusluse uuringutes uusi perspektiive avanud nn rahvusliku loiduse uurimine, mis 19. ja 20. sajandi vahetuse Ida-Euroopa näitel on juhtinud tähelepanu identiteetide mitmekesisusele ja meenutanud, et paljud inimesed ei samastanud ennast esmajoones rahvusega. ${ }^{18}$ Et baltisaksa aines võiks siin kõnekas olla, seda on näidanud Katja Wezeli jt uurimused. ${ }^{19}$ Sageli on rõhutatud, kui raske oli baltisakslastel valida kohaliku ja rahvusliku identiteedi, saksluse ja keisritruuduse vahel. Laiemas plaanis võiksid baltisakslased aga osutuda hoopis heaks näiteks, et piirialade elanikkond on võimeline imperiaalse, regionaalse ja rahvusliku identiteedi põhjal looma erinevaid hübriidseid identiteete. Tähelepanu pööramine rahvuslikule loidusele aitab vältida rahvuslike ja etniliste rühmade käsitlemist liiga ühtsena: see on tõstnud esile alamatest klassidest baltisakslased ning 19. ja 20. sajandi vahetuse Eesti ja Läti linnastunud töölisklassi, kes käisid rahvusliku identiteediga ümber kas loiult või mänguliselt, aga pidid teatud juhtudel rahvuslikule printsiibile alluma - näiteks rahvusriigi loomisel või ümberasumisel. ${ }^{20}$

Siiski tuleb tõdeda, et Eestis on rahvusülese ajaloo käsitlemist kõige enam mõjutanud hoopis kirjandusteadlane Jaan Undusk, keda võib tõenäoliselt pidada 21. sajandil Eesti ajaloolasi kõige enam kõnetanud kohalikuks autoriks (vt Pärtel Piirimäe artiklit siinsamas ajakirjanumbris). Suveräänse mõtlejana Undusk ise rahvusülese ajaloo kontseptsioonist otseselt ei lähtu. Sellegipoolest juhtis Unduski kõige laiemalt

${ }^{16}$ Tourismus im Ostseeraum: Tourism in the Baltic Region. Hrsg. v. K. Brüggemann. (Nordost-Archiv: Zeitschrift für Regionalgeschichte, 20.) Harrassowitz, Wiesbaden, 2012; Rattus, K., Järs, A. Narrated Soviet tourist landscapes during late socialism. - International Journal of Culture, Tourism and Hospitality Research (ilmumas 2020).

${ }^{17}$ Velmet, A. The blank slate e-state: Estonian information society and the politics of novelty in the 1990s. - Engaging Science, Technology, and Society, 2020, 6, 162-184; Annist, A. Otsides kogukonda sotsialismijärgses keskuskülas: Arenguantropoloogiline uurimus. Tallinna Ülikooli Kirjastus, Tallinn, 2011.

${ }^{18}$ Zahra, T. Imagined noncommunities: National indifference as a category of analysis. - Slavic Review, 2010, 69, 1, 93-119.

${ }^{19}$ German community - German nationality? Baltic German perceptions of belonging in the nineteenth and twentieth century. Ed. by K. Wezel, S. Donecker. Journal of Baltic Studies, 2017, 48, 1 (ajakirja erinumber).

${ }^{20}$ Brüggemann, K., Wezel, K. Nationally indifferent or ardent nationalists? On the options for being German in Russia's Baltic provinces, 1905-17. - Kritika: Explorations in Russian and Eurasian history, 2019, 20, 1, 39-62; Plath, U., Vanamölder, K. Kui Liisa kirjutas kirja... - Tuna, 2016, 3, 95-108. 
tsiteeritud tekst tähelepanu baltisaksa ajaloo rahvusülesele dimensioonile. ${ }^{21}$ Ajaloolased kritiseerisid küll teravalt tema keskset väidet, mis puudutas Balti autonoomia idee pikka kestust ja järjepidevust ning sidus ühte baltisaksa eliidi ja haritlaste ning eesti rahvuslaste pürgimused, ometi võtsid nad vähemalt idee tasandil omaks Unduski üleskutse luua maiskondlikku ajalugu, vaadata siinset ajalugu regionaalsest ja baltisakslasi kaasavast vaatenurgast. ${ }^{22}$ Selle mõttega on valdavalt positiivselt suhestunud ka need Eesti ajaloolased, kes rahvusülest, põimitud või globaalset ajalugu puudutavate debattidega või üldisemaltki teooriaga muidu eriti ei tegele. Kõige ulatuslikumalt on Unduski pakutud maiskondlikku lähenemist siinsele ajaloole ja kultuurile seni rakendanud kirjandusteadlased, seda ka in spe ilmuvas Baltimaade kirjakultuuri ajaloos (peatoimetaja Liina Lukas). ${ }^{23} \mathrm{Ka}$ teine Unduski mõjukas käsitlus, Garlieb Helwig Merkeli, Carl Robert Jakobsoni ja Jakob Hurda ajalookäsitluse võrdlus, toob fookusesse põimingud eesti ja (balti)saksa tüvitekstide vahel. ${ }^{24}$ Eesti kultuuri, rahvusluse ja ajalookirjutuse rahvusüleseid seoseid teiste traditsioonidega ongi kõige enam esile tõstetud valgustusega seoses. See on jätnud varju teised põimingud, antud perioodi puhul näiteks seosed konservatiivsema baltisaksa diskursusega või Vene keisririigis levinud mitmesuguste ideede ja ideoloogiatega. ${ }^{25}$ Nagu edaspidi nähtub, saaks maiskondlikkuse printsiipi veelgi avardada, kui võtta tekstide ja diskursuste kõrval tõsiselt arvesse ka keskkonda, taristut jm.

Samuti on põimingutega tegeletud eelkõige tekstide ja diskursuste tasandil ning märksa vähem analüüsitud nende seoseid ühiskonnaga - kuigi Unduski maiskondliku ajaloo kontseptsiooni keskmes on arusaam diskursuse vägagi poliitilisest mõjust ehk siinse piirkonna autonoomia ideest. Balti kontekstis pakub ühe võimaluse mõelda diskursuste seostest võimu ja ühiskondlike suhetega kolonialism. Teatavasti ei ole vaidlused selle üle, kas ja millisel moel saab Euroopa ajalugu käsitleda kolonialismi võtmes ja postkoloniaalse teooria raamistikus, kaugeltki lõppenud. Eesti ajaloolaste seas on alates 2000. aastatest kolonialismi märksõna olnud keskaja uuringutes laialt kasutusel. See peegeldab medievistikas 1990. aastatel alanud arengut - huvi koondumist Euroopa keskaegsele ekspansioonile ja katseid sobitada sellele postkoloniaalses teoorias levinud tõlgendusi. Eestis võeti need ideed kasutusele, kuid sügavamat arutelu kolonialismiga seotud mõistete kasutamise üle ei tekkinud, sh ka selliste põhiliste küsimuste üle, mil moel ja määral saab keskaja puhul üldse kolonialismist kõnelda. Põhjalikuma diskussiooni puudumine avaldab olulist mõju ka kolonialismi käsitlemisele hilisemate perioodidega seoses. Keskaja-uuringutes laiemalt tõi postkoloniaalne pööre kaasa huvi koloniseerija ja koloniseeritu suhete,

${ }^{21}$ Undusk, J. Ajalootõde ja metahistoorilised žestid: Eesti ajaloo mitmest moraalist. - Tuna, 2000, 2, 114-130

${ }^{22}$ Brüggemann, K. Rahvusliku vaenlasekuju demontaažist ehk Carl Schirren kui Eesti iseseisvuse rajaja? - Tuna, 2002, 3, 93-98; Jansen, E. Tagasi ajalukku. - Tuna, 2003, 2, 131-136; Undusk, J. Eesti ajaloo kotkaperspektiivist: Minu vaidlus Brüggemanniga. - Tuna, 2002, 3, 99-116.

${ }^{23}$ Entangled cultures in the Baltic region. Ed. by E. Laanes. Journal of Baltic Studies, 2020, 51, 3 (ajakirja erinumber).

${ }^{24}$ Undusk, J. Kolm võimalust kirjutada eestlaste ajalugu: Merkel - Jakobson - Hurt. - Keel ja Kirjandus, 1997, 11, 721-734; 12, 797-811.

${ }^{25}$ Kaljundi, L.; Plath, U. Eesti ajalookirjutus põimitud perspektiivist. - Tuna, 2017, 1, 2-6. 
hübriidsuse, „teise“ ja „võõra“ kuvandi jm vastu. Eestis kõneldi ja kõneletakse seniajani kõige enam maastiku koloniseerimisest - see vaatenurk on kujundanud ümber keskaegse arhitektuuri- ja asustusloo uurimise ${ }^{26}$ kuid siin peegeldub ka ruumilise pöörde ja kultuurigeograafia mõju. ${ }^{27}$

Arvestades, kuivõrd pika aja vältel võib Eesti aladel näha kolonialismi avaldumist selle eri vormides, oleksid ulatuslikumad debatid tänuväärsed nii kohalikus kui ka laiemas kontekstis. Kuidas määratleda kolonialismi, selle eksisteerimise vorme, kestust ja järelmõju? Senised uurimused on keskendunud 19. ja 20. sajandile ning peamiselt kolonialismi diskursiivsetele avaldustele. Nende tugevuseks on globaalse dimensiooni sissetoomine, näidates, kui tihedalt on baltisaksa ja eesti kultuur ja identiteet põimunud globaalse koloniaaldiskursusega. ${ }^{28}$ Samuti on see uurimistöö demonstreerinud, et koloniaaldiskursus tõuseb Eesti ajaloos esile globaalse koloniaalekspansiooni võtmeperioodidel (varauusajal, 19. sajandil) ning sellega seotud konfliktide, nt abolitsionistliku liikumise ajal. Postkoloniaalsetele uuringutele iseloomulikult on ka Eesti ainesega seoses esile toodud koloniseerija ja koloniseeritu keeruline ja ärev sõltuvussuhe, mida on rohkem analüüsitud seoses koloniaalse pärandi ja paine mõjuga eesti kultuurile. ${ }^{29}$ Postkoloniaalsete uuringute klassikalise teema, koloniseerija loodud „teise“ kuvandi omaksvõtmise ja kohandamisega on Eestis tegeletud folkloori ja visuaalkultuuri uuringutes - kõige silmatorkavamalt puudutab see algselt koloniaaldiskursuse raames loodud etnograafiliste kuvandite omaksvõtmist ja tähtsust Eesti identiteedis. ${ }^{30}$ Diskursuste kõrval on kolonialismi ühiskondlikud ja poliitilised avaldused seni palju vähem tähelepanu pälvinud, ehkki nende tasandite lõimimine pakuks võimalust mõtestada ümber Eesti ajaloo keskseid teemasid: näiteks viimasel ajal uuesti tähelepanu pälvinud (päris)orjuse ühiskondlik ja mõisteline aja$\operatorname{lugu}^{31}$ seostub kolonialismi ja koloniaaldiskursuse arenguga nii kohalikul kui globaalsel tasandil. Huvipakkuv võiks olla ka Eesti ajaloo seostamine Vene impeeriumi

${ }^{26}$ Markus, K. Visual culture and politics in the Baltic Sea region, 1100-1250. Brill, Leiden, 2020.

${ }^{27}$ Nugin, R., Jaago, T., Kannike, A., Kull, K., Palang, H., Printsmann, A., Siim, P. M., Lindström, K. A plurality of pasts and boundaries: evidence from Estonia's last one hundred years. - Interdisciplinary approaches to cultural theory. Ed. by A. Kannike, K. Pärn, M. Tasa. (Approaches to Culture Theory, 8.) University of Tartu Press, Tartu, 2020, lk 334-373; Palang, H., Sooväli, H., Printsmann, A., Peil, T., Kaur, E.; Lang, V., Konsa, M., Külvik, M., Alumäe, H., Sepp, K. Püsivad ja muutuvad maastikud Eestis: Kultuurigeograafiline käsitlus. - Akadeemia, 2005, 10, 2209-2227.

${ }^{28}$ Plath, U. Esten und Deutsche in den baltischen Provinzen Russlands: Fremdheitskonstruktionen, Lebenswelten, Kolonialphantasien 1750-1850. Harrassowitz, Wiesbaden, 2011; Monticelli, D., Peiker, P., Mits, K. Jamaicast Pariiisi ning sealt Tartusse tagasi: Lydia Koidula maailmavaatest ja mugandamisstrateegiatest tema saksa eeskujude valguses. - Keel ja Kirjandus, 2018, 12, 915-941.

${ }^{29}$ Kirss, T.-A. Rändavad piirid: postkolonialismi võimalused. - Keel ja Kirjandus, 2001, 10, 673682.

${ }^{30}$ Jääts, I., Metslaid, M. Eesti etnograafia ja eesti rahvuslus. - Keel ja Kirjandus, 2018, 1-2, 118 135. Põldvee, A. Vanemuise sünd: Lisandusi eesti pseudomütoloogia ajaloole. - Tuna, 2013, 1, 10 31; Kivimaa, K. Rahvuslik ja moderne naiselikkus. Tartu, Tartu Ülikooli Kirjastus, 2009.

${ }^{31}$ Küng, E., Loit, A., Kroon, K., Põldvee, A., Seppel, M. Eesti- ja Liivimaa talurahva olukorrast Rootsi aja lõpus. - Ajalooline Ajakiri, 2013, 3, 375-403; Seppel, M. The semiotics of serfdom: How serfdom was perceived in the Swedish conglomerate state, 1561-1806. - Scandinavian Journal of History, 2020, 45, 1, 48-70; Seppel, M. Mis on pärisorjus? - Õpetatud Eesti Seltsi aastaraamat 2007. Õpetatud Eesti Selts, Tartu, 2008, 179-191. 
kolonialismi vormidega. näiteks põhjarahvastega seotud „teise“ kuvandite ja hierarhiatega, kuid samuti Baltimaade elanike osalusega koloniaalses ekspansioonis. ${ }^{32}$

Põhjalikult on postkoloniaalse teooria rakendamise üle Eesti ajaloos arutletud seoses nõukogude perioodiga - ka sellega on tegelenud eriti just kirjandusteadlased, kaasates rahvusüleseid võrdlusi. ${ }^{33}$ Hea platvormi edasisteks aruteludeks ja vaidlusteks on loonud Epp Annuse poolt käibele toodud termin ,sotskolonialism“. ${ }^{34}$ Defineerides kolonialismi ühe populatsiooni allutamisena teise, oma piire laiendava ning vallutatud territooriumi poliitilisi ja kultuurilisi institutsioone muuta taotleva riigi poolt, tõlgendab ta sotskolonialismi kolonialismi ühe vormina, kus koloniaalsed strateegiad on lahutamatud kommunistliku ühiskonna ülesehitamise püüdest. Siin on ajaloolased osutanud ohule, et kolonialismi käsitletakse lihtsustatud tähenduses, rõhutades Nõukogude võimu taotlust siinset kultuuri ja institutsioone totaalselt ümber kujundada ${ }^{35}$ Koloniaaluuringud, eriti ,uus imperiaalne ajalugu“"36 rõhutavad kolonialismianalüüsis just koloniaalsuhete haprust, diskursiivse teisestamise tinglikkust ja tegelike võimusuhete vastuolulisust, piiratust ja mitmepoolsust. Ka Annus rõhutab, et koloniaalne analüüs võimaldab küsida, millised olid koloniaalvõimu piirid, sisemised lahkhelid, mil määral tugines Nõukogude impeerium valitsemises kohalikule eliidile ja mugandus ise selle taotlustega. Selle teema ulatuslikumaks käsitlemiseks oleks edaspidi oluline kaasata rohkem erinevat ajaloolist ainest, eriti mitteilukirjanduslikke tekste, mis võimaldaksid analüüsida seoseid ja erisust kolonialismi representatiivse tasandi (diskursuste, fantaasiate ja traumade) ning praktiliste võimusuhete (poliitiliste ja juriidiliste institutsioonide, kultuuri-, keskkonna- ja tööstuspoliitika, igapäevase administratsiooni jm) kujunemise vahel. ${ }^{37}$

\section{MÄLU-UURINGUD}

Mälu-uuringud on kindlasti üks end Eesti ajalooteaduses 2000. aastatel kõige edukamalt kehtestanud uurimissuundi. Mälust on saanud üks peamisi uurimisteemasid kogu

${ }^{32}$ Plath, U. „Euroopa viimased metslased”: eestlased saksa koloniaaldiskursis 1770-1870. - Rahvuskultuur ja tema teised. Toim R. Undusk. (Collegium litterarum, 22.) Underi ja Tuglase Kirjanduskeskus, Tallinn, 2008, 37-64.

${ }^{33}$ A Postcolonial view on Soviet era Baltic cultures. Ed. by E. Annus. Journal of Baltic Studies, 2016, 47, 1 (ajakirja erinumber); Baltic postcolonialism. Ed. by V. Kelertas. Rodopi, Amsterdam, 2006.

${ }^{34}$ Annus, E. Soviet postcolonial studies: A view from the western borderlands. Routledge, London, 2018; Annus, E. Sotskolonialism Eesti NSV-s: Võim, kultuur, argielu. Tartu Ülikooli Kirjastus, Tartu, 2019.

${ }^{35}$ Brüggemann, K. Wie postkolonial ist der Poststalinismus Oder „Let the Hegemon Speak“: Anmerkungen zu zwei Neuerscheinungen. - Forschungen zur baltischen Geschichte, 2019, 14, 213 223.

${ }^{36}$ A new imperial history: Culture, identity and modernity in Britain and the empire, 1660-1840. Ed. by K. Wilson. Cambridge University Press, Cambridge, 2004; Hall, C. Civilising subjects: Metropole and colony in the English. imagination, 1830-1867. Polity Press, Cambridge, 2002; Cooper, F. Colonialism in question: Theory, knowledge, history. University of California Press, Berkeley, 2005.

${ }^{37}$ Annus, E., Peiker, P., Lukas, L. Colonial regimes in the Baltic states. - Interlitteraria, 2013, 18, 2, 545-554. 
maailmas ning seda tänu globaalsetele muutustele ja vajadusele ühiskondliku mälutöö järele. Samuti on mälu-uuringuid toetanud üldisemad arengusuunad humanitaarteadustes, mida 1990. aastateks iseloomustasid teadlikkus ajaloo, pärandi ja teadmiste konstrueeritusest ning nende tihedatest seostest rahvusluse ja võimuga - oma osa nendes muutustes oli ka koloniaalajaloo ja postkoloniaalsete uuringute esiletõusul.

Praeguseks on mälu-uuringud märkimisväärselt rahvus- ja valdkondade-ülene uurimisväli. See on kujundanud ka Eesti mälu-uuringute näo, mis lõimib lisaks ajaloole selliseid distsipliine nagu etnoloogia, sotsioloogia, kirjandusteadus, visuaalkultuuri uuringud, filosoofia jt. Rahvusvahelises plaanis paigutub Eesti enamasti Ida-Euroopa ajaloomälu uurimise konteksti: uurimistöö keskmes on mälutöö 20. sajandi traumade kallal, mälukonfliktid ning katsed otsida Nõukogude repressioonidele kohta globaalsel areenil, mida iseloomustavad võitlused andekspalumise ja ohvriksolemise poliitika ümber. Siin on oluline mitte jääda üksnes veel ühe võrdlusmaterjali esitajaks, vaid pakkuda omalt poolt välja uurimisprobleeme ja tõlgendusraame: värske näide on kirjandusteadlase Eneken Laanese projekt, mis analüüsib Ida-Euroopa traumakogemuse tõlkimist Läänele ja maailmale globaalselt arusaadavasse keelde. ${ }^{38}$ Võrdlusi Ida-Euroopa ja Baltikumiga on loonud ka mitmed teised uurijad, kõrvutades mälu konstrueerimist muuseumides, kirjanduses, omaelulugudes jm. ${ }^{39}$

Palju tähelepanu on pälvinud mälukonfliktid nii riikide vahel kui ka post-nõukogude ühiskondades endis. Pronkssõduri kriisi (2007) tõttu on Eesti juba ammu sattunud teemaga tegelevate uurijate huviorbiiti. ${ }^{40}$ Kuid selle kõrval on mitmed uurimused Eesti mälupoliitikat käsitlenud ka pikemas vaates. Nüüdse olukorra taustal võivad just nende järeldused olla eriti olulised: ehkki Eesti identiteedinarratiivis valitseb lugu kiirest läänelike vaadete omaksvõtmisest, osutavad mitmed uurimused 1990. aastate (mälu)poliitika konservatiivsusele. Restauratiivse ajaloopoliitika mõjukust Eesti iseseisvuse taastamise ajal on analüüsinud Ene Kõresaar, Marek Tamm jt. ${ }^{41}$ Selle kõrval on politoloog Vello Pettai rõhutanud õiguslikku restau-

${ }^{38}$ ERC grant „Tõlkides mälusid: Ida-Euroopa minevik globaalsel areenil“, Tallinna Ülikool, 2020 2024.

${ }^{39}$ Narratives of exile and identity: Soviet deportation memoirs from the Baltic countries. Ed. by V. Davoliūtè, T. Balkelis. Central European University Press, Budapest, 2018; Kattago, S. Memory and representation in contemporary Europe; The persistence of the past. Ashgate, Farnham, 2012; Contested and shared places of memory: History and politics in North Eastern Europe. Ed. by J. Hackmann, M. Lehti. Journal of Baltic Studies, 2008, 39, 4 (ajakirja erinumber); Velmet, A. Occupied identities: Constructing national identity in Baltic museums of occupations. - Journal of Baltic Studies, 2011, 42, 2, 189-211.

${ }^{40}$ Astrov, A. States of sovereignty. - Russian Politics and Law, 2009, 47, 5, 66-79. Smith, D. J. 'Woe from stones': Commemoration, identity politics and Estonia's 'war of monuments'. - Journal of Baltic Studies, 2008, 39, 4, 419-430. Brüggemann, K., Kasekamp, A. The politics of history and the "war of monuments" in Estonia. - Nationalities Papers, 2008, 36, 3, 425-448; Monumentaalne konflikt: Mälu, poliitika ja identiteet tänapäeva Eestis. Toim P. Petersoo, M. Tamm. Varrak, Tallinn, 2008.

${ }^{41}$ Kõresaar, E. Elu ideoloogiad: Kollektiivne mälu ja autobiograafiline minevikutõlgendus eestlaste elulugudes. Tartu: Eesti Rahva Muuseum, 2005; Tamm, M. In search of lost time: Memory politics in Estonia, 1991-2011. - Nationalities Papers, 2013, 41, 4, 651-674. 
ratsiooni, näidates, kuidas riigi legitiimsuse rajamine sõdadevahelise vabariigi järjepidevusele mõjutas Eesti omandi- ja kodakondsuspoliitikat. ${ }^{42}$ Lisaks on Eva Clarita Pettai osutanud kasinale ühiskondlike arutelude traditsioonile: Eestis 1990. ja 2000. aastatel nõukogude ja natsionaalsotsialistlike repressioonide uurimiseks ellu kutsutud institutsioonid ei soosinud avalike diskussioonide teket. ${ }^{43}$

20. sajandi kõrval on varasemasse minevikku puutuvalt käsitletud küllaltki piiratud hulka teemasid - peamiselt on pööratud tähelepanu rahvusliku ajaloo tuumiknarratiivile (eestlaste igavene vabadusvõitlus) ja olulisematele mälupaikadele: Jüriöö ülestõus, Mahtra sõda, Vabadussõda. ${ }^{44}$ See on endaga kaasa toonud probleemi, millele osutati juba seoses Pierre Nora teedrajava Prantsuse mälupaikade kogumikuga: isegi kui uurimistöö eesmärgiks on rahvusliku mälu dekonstrueerimine, jätab keskendumine suurtele mälupaikadele varju ajaloomälu paljususe ja peavooluga vastuollu minevad mälestused. 2011. aastal eristas Astrid Erll mälu-uuringutes kolm faasi: esiteks 20. sajandi alguse teooriad, mis osutasid mälu ühiskondlikule raamistikule (Maurice Halbwachs jt); teiseks Nora algatatud mälupaikade projekt 1980.-1990. aastatel, mis tõstis esile rahvusriigi kui mälu peamise ühiskondliku raamistiku. Kolmanda faasi tõid Erlli väitel kaasa 21. sajandi algusele iseloomulikud arengud ühiskonnas ja ülikoolides, see tekitas vajaduse mõtestada mälu-uuringuid uuesti: otsida alternatiive metodoloogilisele natsionalismile ning käsitleda mälu rahvusülesest ja globaalsest perspektiivist. ${ }^{45}$

Eestis on mälu mitmehäälsuse, konkureerivate ja vastumälude olemasolu hästi välja toonud etnoloogide uurimused, mis keskenduvad nõukogude aja mäletamisele. ${ }^{46}$ Alates 1980 . aastate lõpust on nõukogude perioodi õpikutes, poliitikute sõnavõttudes jm rahvusliku ajaloomälu peavoolu väljendustes defineeritud märksõnad „kannatus“ ja „katkestus“, samuti suured vastandused, nagu „,vastupanu“ ja „kollaboratsionism“, ,,ametlik“ ja „mitteametlik“, ,privaatne“ ja ,avalik“. Omaeluloolisele materjalile tuginevates uurimustes avaneb nõukogude aja mäletamisega seoses siiski märksa mitmekesisem pilt, kus valikud ei ole kaugeltki mustvalged. Kontrast vastandustele üles ehitatud mälupoliitika ja kollektiivse mälu mitmehäälsuse vahel on iseloomulik ka teistele Ida-Euroopa maadele. ${ }^{47}$ Suured dihhotoomiad on kahtluse alla seadnud mitmed hilise nõukogude aja uurimused,

${ }^{42}$ Pettai, V. The construction of state identity and its legacies: Legal restorationism in Estonia. - Ab Imperio, 2007, 3, 1-23.

${ }^{43}$ Pettai, E.-C. Establishing „holocaust memory“: A comparison of Estonia and Latvia. - Historical memory culture in the enlarged Baltic Sea region and its symptoms today. Ed. by O. Rathkolb, I. Sooman. Vandenhoeck \& Ruprecht, Göttingen, 2011, 159-174; Pettai, E.-C., Pettai, V. Transitional and retrospective justice in the Baltic states. Cambridge University Press, Cambridge, 2015.

${ }^{44} \mathrm{Nt}$ artiklid ajakirjas Vikerkaar (2003, 10/11); vt samuti Tamm, M. Monumentaalne ajalugu: Esseid Eesti ajalookultuurist. Kultuurileht, Tallinn, 2012.

${ }^{45}$ Erll, A. Travelling memory. - Parallax, 2011, 17, 4, 4-18.

${ }^{46}$ Jõesalu, K., Kõresaar, E. Continuity or discontinuity: On the dynamics of remembering ,mature socialism" in Estonian post-Soviet remembrance culture. - Journal of Baltic Studies, 2013, 44, 2 , 177-203; Soldiers of memory: World War II and its aftermath in Estonian post-Soviet life stories. Ed. by E. Kõresaar. Rodopi, New York, Amsterdam, 2011.

${ }^{47} \mathrm{Nt}$ Baltic socialism remembered: Memory and life story since 1989. Ed. by E. Kõresaar. Journal of Baltic Studies, 2016, 47, 4 (ajakirja erinumber). 
seda nii rahvusvaheliselt kui ka Eestis, kus seda perioodi on peamiselt mõtestanud kunstiajaloolased. ${ }^{48}$

Nagu on näidanud etnoloog Kirsti Jõesalu, on 2000. aastatel muutunud ka Eesti mälukultuur ise: nõukogude ajaga seostuvad neutraalsed või positiivsed mälestused kerkisid järk-järgult esile muuseumides ja meedias, samuti omaelulugudes. ${ }^{49}$ Siin avaldub hästi ka kollektiivsele mälule iseloomulik dünaamika. Mälu mitmehäälsus tuleb välja ka teiste omaeluloolise materjaliga tegelevate uurijate töödes, näiteks on repressioonide mäletamise uurimisel välja toodud vajadus tegeleda naiste kogemuse eripäraga ${ }^{50} \mathrm{Küll}$ aga on omaette suure valdkonnana paljuski kirjeldamata ja analüüsimata eestivenelaste mälu.

Mälupoliitika kõrval on Eestis laialdaselt kasutusele võetud ka kultuurimälu mõiste, mille toel on analüüsitud eri meediumite (monumentide, kirjanduse, teatri, maastiku, visuaalkultuuri jm) osalust ajaloomälu kujunemisel ${ }^{51}$ Kui Eesti kultuurimälu uuringud on üldiselt olnud küllaltki tihedalt seotud ka mälupoliitika analüüsimisega, siis lisaks võiks nende puhul olla edasiviivaks mälu varasemate ja mitmekultuuriliste kihistuste, sh baltisaksa ja (eesti)vene pärandi kaasamine. Siin tekib ühisosa ka rahvusülese ja koloniaalse ajaloo teemadega, mis on mälu-uuringuid rahvusvahelises plaanis tugevalt mõjutanud. Häid võimalusi pakub ka kultuurimälu uuringutes keskseks küsimuseks tõusnud intermediaalsuse analüüs, kuna Eesti suhtelise väiksuse tõttu on võimalik uurida erinevate kultuurimälu meediumite koostoimet ühe või teise mälupaiga kujunemisel. Hiljuti on seda hästi demonstreerinud Tartu Ülikooli semiootikute transmeedia uurimisgrupp. Mälu-uuringute keskmes ongi järjest rohkem meediaga seostuvad küsimused, mälu digitaliseerumine ja globaliseerumine. Samuti räägitakse mälu-uuringute ümbermõtestamise vajadusest antropotseeni ajastul ja võimalustest lõimida seda keskkonna-uuringutega. ${ }^{52}$ See on tõstatanud küsimuse, kas mälu-uuringud peaksid 21. sajandil jõudma oma neljandasse, posthumaansesse faasi. Seega peegelduks mälu-uuringutes ajaloo pluraliseerumise uus etapp: valgete meeste suurte tegude kõrval on järk-järgult kaasatud

${ }^{48}$ Talvoja, K. Karm stiil eesti kunstiajalookirjutuse kontekstis = Severe style in the context of Estonian art history writing. Eesti Kunstiakadeemia, Tallinn, 2019; Kurg, A. Boundary disruptions: LateSoviet transformations in art, space and subjectivity in Tallinn 1968-1979. Eesti Kunstiakadeemia, Tallinn, 2014. Ülevaatlikult vt: Annus, E. Rahvuslik, mitterahvuslik: Mõtestades Eesti NSV aegseid protsesse kunstide valdkonnas. - Kunstiteaduslikke Uurimusi, 2020, 30, 1/2, 185-194.

49 Jõesalu, K. Dynamics and tensions of remembrance in post-Soviet Estonia: Late socialism in the making. Tartu Ülikooli Kirjastus, Tartu, 2017.

${ }^{50}$ Kurvet-Käosaar, L. „Is that hunger haunting the stove?“ Thematization of food in the deportation narratives of Baltic women. - Journal of Baltic Studies, 2015, 46, 3, 337-352; She who remembers survives: Interpreting Estonian women's post-Soviet life stories. Ed. by T. Kirss, E. Kõresaar, M. Lauristin. Tartu University Press, Tartu, 2004.

${ }^{51}$ Kaljundi, L., Kreem, T.-M. Ajalugu pildis - pilt ajaloos: Rahvuslik ja rahvusülene minevik eesti kunstis. Kumu kunstimuuseum, Tallinn, 2018. Kruuspere, P. Eesti näitekirjandus ja teater kultuurimälu meediumidena. - Philologia Estonica Tallinensis, 2017, 2, lk 35-58; Novels, histories, novel nations: Historical fiction and cultural memory in Finland and Estonia. Ed. by L. Kaljundi, E. Laanes, I. Pikkanen. Finnish Literature Society, Helsinki, 2015; Tamm, M. Monumentaalne ajalugu.

${ }^{52}$ Craps, S. Introduction: Memory studies and the anthropocene: A roundtable. - Memory Studies, 2017, 11, 4, 498-515. 
marginaliseeritud klassid ja rassid, naised ja lapsed, vähemused jt, nüüd oleks järg mitteinimeste, asjade, looduse ja keskkonna käes.

\section{TEADUS-, TEHNOLOOGIA- JA MEDITSIINIAJALUGU}

Rahvusliku ajalookirjutuse kehtestatud tajutava jaotuskorra ületamiseks võiks vaadata viimaste aastate teadus- ja keskkonnaajaloolaste ning nendega seotud interdistsiplinaarsete õpetlaste tööde suunas. Muidugi ei seisa need valdkonnad rahvuslikust ajalookirjutusest täiesti eraldi. Ka teadusajaloost võib leida rahvuslikke saavutusi esindavate staarteadlaste pjedestaalile tõstmist ning keskkonnaajaloost rahvusliku kuuluvuse sidumist looduslähedusega. Järgnevalt keskendume aga nendele teadus- ja keskkonnaajaloolistele töödele, mis võimaldavad traditsioonilise ajalooteaduse piiride nihutamist.

Viimastel aastatel on globaalse keskkonnakriisi teadvustamine motiveerinud teadus- ja keskkonnaajaloolasi kõikjal maailmas oma tavapäraseid uurimisraame ümber mõtestama ning kasvatanud seeläbi kahtlemata ka oma valdkondade ühiskondlikku tähelepanu. Teadusajaloolaste jaoks on kliimamuutuste ümber käiv debatt tõstatanud uuel ja tungival moel ekspertiisi ja tõe problemaatika. See on pikalt olnud teadusfilosoofias üks põhilisi debatte, aga just viimastel kümnenditel muutunud USA kultuurisõdade, kliimaskeptikute, vaktsiinivastaste ja niisama vandenõuteoreetikute jõul akadeemilisest arutelust vägagi aktuaalseks küsimuseks. ${ }^{53} \mathrm{Nii}$ on teadusajaloolased laiendanud oma tööpõldu ja uurinud, kuidas formaalse ekspertiisita inimesed - pärismaalastest informandid, patsiendid, hobiteadlased jt - on mõjutanud teadusmõtte arengut. ${ }^{54}$

Samas on antropotseen - inimtegevuse mõju geoloogilistele ja ökoloogilistele protsessidele planetaarsel tasandil - näidanud, kuivõrd on kõik inimtegevuse aspektid fossiilkütuste ajal läbi põimitud looduskeskkonna muutustega, ja toonud sellega keskkonnaajaloo ka teiste valdkondade horisondile. ${ }^{55}$ Teadus- ja tehnoloogiaajaloolaste jaoks tähendab see suurendatud rõhku uurimustele, mis keskenduvad fossiilkütustel põhineva majanduse jaoks vajaliku innovatsiooni ja ekspertteadmiste konstrueerimise ajaloole. Ent antropotseen tähendab ühtlasi, et keskkonnaküsimused tungivad ka traditsioonilisemate ajaloolaste pärusmaale. Nii võib näha üha rohkem monograafiaid, mis käsitlevad näiteks kliimamuutuste mõju rahvusvahelistele suhetele, impeeriumide tõusule ja langusele, poliitiliste ideoloogiate arengule ning mõistagi ka vastupidi - kõigi „tavaliste“ ajalooliste protsesside mõju kliimale ja ökosüsteemidele. ${ }^{56}$

\footnotetext{
${ }^{53}$ Oreskes, N., Conway, E. Merchants of doubt: How a handful of scientists obscured the truth on issues from tobacco smoke to global warming. Bloomsbury, New York, 2010.

${ }^{54}$ Jasanoff, S. Designs on nature: Science and democracy in Europe and the United States. Princeton University Press, Princeton, NJ, 2005.

${ }^{55}$ Chakrabarthy, D. The climate of history: Four theses. - Critical Inquiry, 2009, 35, 2, 197-222.

${ }^{56}$ Degroot, D. The frigid golden age: Climate change, the little ice age, and the Dutch Republic, 1560 1720. Cambridge University Press, Cambridge, 2018; Demuth, B. Floating coast: An environmental history of the Bering Strait. W. W. Norton, New York, 2019.
} 
Teiseks on globaalne keskkonnakriis koondanud teadus- ja keskkonnaajaloolaste tähelepanu küsimusele „Kes süütas selle tulekahju?““ ${ }^{57}$ Teisisõnu, lisaks episteemilistele küsimustele teaduse ja mitteteaduse, kultuuri ja looduse vaheliste piiride konstrueerimisest uurivad ajaloolased aina rohkem võimu jaotumise, vastutuse ja vägivallaga seotud küsimusi. Kelle otsuste, milliste poliitiliste, majanduslike ja episteemiliste süsteemide mõjul on planeedi ökoloogiliste ressursside ekspluateerimine rikastanud ühtesid ning vaesestanud teisi inimesi ja olendeid? Kes on võitjad, kes kannatajad? Kuidas on inimtegevuse ökoloogilisi tagajärgi üritatud mõista või varjata? Võimumehhanismide uurimiseks võib seetõttu just seesugustest rahvusvahelistest uurimustest häid tööriistu leida.

Inimeste ja looduse vahelise eristuse tinglikkust rõhutavad ja selle ajalugu käsitlevad uurimused ei ole Eesti humanitaarias võõrad, vastupidi, on isegi väidetud, et Eesti keskkonnamõte on muust maailmast mõnevõrra ees olnud - kuigi, nagu tagapool näha, on meie keskkonnahumanitaarsed uurimused globaalse ja distributiivse õiglusega tegelevatest uurimustest vägagi erineva rõhuasetusega. Antropotseeni mõiste puhul on välja toodud selle sarnasust Jakob von Uexkülli Umwelt'iga, aga ka Juri Lotmani semiosfäriga, mis toetub omakorda Vladimir Vernadski biosfääri ja noosfääri mõistele, mis antropotseeni ajastul on taasavastatud. ${ }^{58}$ 2011. aastal rajatud keskkonnaajaloo keskus (KAJAK) on omakorda aidanud konverentside, näituste, teadus- ja aimekirjanduse ning õppetöö kaudu valdkonnas rahvusvaheliselt keskseid debatte Eestis tutvustada ja edasi arendada. ${ }^{59}$ Alustades esimestest toiduajaloo-teemalistest konverentsidest 2012. aastal, võiks KAJAK-i arendustöö seniseks kulminatsiooniks pidada tinglikult ühelt poolt ajakirjade Horisont ja Vikerkaar teemanumbreid 2015. ja 2016. aastal, teisalt Euroopa keskkonnaajaloolaste aastakonverentsi 2019. aastal. ${ }^{60}$ Sarnane institutsionaliseerumine on toimunud ka teadusajaloos, kus peamisteks poolusteks on 2006. aastast järjepidevalt iga kahe aasta tagant korraldatavad Balti teadusajaloo konverentsid ja 2013. aastal asutatud ajakiri Acta Baltica Historiae et Philosophiae Scientiarum. ${ }^{61}$ Teadusajalugu on veetud pigem kõrvalvaldkondades - filosoofias, loodus- ja meditsiiniteadustes. KAJAK on leidnud oma institutsionaalse kodu Tallinna Ülikooli ajaloo, arheoloogia ja kunstiajaloo keskuses, ent ka siin on interdistsiplinaarsus mänginud valdkonna arengus kriitilist rolli. ${ }^{62}$

Eesti teadusajaloo puhul torkab silma teisteski valdkondades täheldatud lõhe teoreetiliste arutelude elavuse ja empiirilise uurimustöö konservatiivsuse vahel.

${ }^{57}$ Malm, A. Kes süütas selle tulekahju? - Vikerkaar, 2019, 1-2, 129-165.

${ }^{58}$ Tamm, M., Kull, K. Eesti teooria - Akadeemia, 2015, 4, 579-625.

${ }^{59}$ Plath, U. Environmental history in Estonia. - Environment and History, 2012, 18, 2, 1-4; Tüür, K. The Estonian environmental history scene: Publications, exhibitions, outreach. - Environment and History, 2016, 22, 4, 665-668

${ }^{60}$ Keskkonnaajaloo eri. Horisont, 2015, 5; Tähelepanu: antropotseen. Vikerkaar, 2016, 6; vt ka: Ökovisioonid. Vikerkaar, 2019, 9; Plath, U., Lindström, K. Singing on the submarine: Conference review for ESEH 2019, „Boundaries in/of environmental history“, Tallinn. - Environment and History, 2020, 26, 1, 140-142.

${ }^{61}$ Ülevaate konverentsidest leiab veebist: http://www.bahps.org/acta-baltica.

${ }^{62}$ Raudkivi, P. Paar seletust KAJAKu asjus. - Tuna, 2012, 15, 4, 141-143. 
Teadusajaloo ja -filosoofia aastakonverentsidel võidakse - võib kahtlustada, et osaliselt mainekujunduslikel põhjustel - keskenduda sellisele teemale nagu „tõejärgsus", ent publitseeritud uurimustes jäädakse pigem teadusvaldkondade sisemise loogika arengu selgitamise juurde, selmet valdkondade piire, tõekriteeriume, meetodeid või praktikaid problematiseerida ja nende teket ajalooliselt kontekstualiseerida.

Laias laastus võib viimaste kümnendite teadusajaloo jaotada kolmeks: Tartu Ülikooliga seotud kanooniliste õpetlaste elu- ja mõttelood; energeetika, eriti põlevkivitööstuse arengulugu, mis seostub laiemalt tehnoloogia- ja tööstusajalooga; ja meditsiiniajalugu fookusega sõdadevahelise aja sotsiaalhügieenil ja eugeenikal.

Neist kolmest liinist kõige mahukam on Tartu Ülikooli teadlastega seotud kirjandus, mille keskmes on suuresti olnud „suurte meeste suured mõtted“ - klassikalist teaduslugu mõjutanud Eesti alalt pärit teadlased. Metodoloogiliselt on need uurimused jäänud enamasti klassikalise teadusajaloo piiridesse, keskendudes näiteks mõne tähelepanuta jäänud teadlase biograafilisele analüüsile või mõne tähelepanuta jäänud idee asetamisele laiemasse mõtteloo konteksti. Seda mudelit järgivad muu hulgas uurimused loodusfilosoofia nn Balti traditsioonist, näiteks Erki Tammiksaare ja Ken Kallingu uurimused Karl Ernst von Baeri vastuseisust darvinismile või Jaan Unduski analüüs nobelisti Wilhelm Ostwaldi monistlikust loodusfilosoofiast. ${ }^{63}$ Kunstiteadlane Epi Tohvri on uurinud põhjalikult Tartu Ülikooli taaskäivitaja, Georges Frédéric Parrot' eluteed, väiksemas mahus biograafilisi uurimusi on ilmunud mitmesuguste tähtpäevade ja juubelite puhul. ${ }^{64}$ Sarnaseid, samuti isiklikele või institutsionaalsetele biograafiatele keskenduvaid ülevaateid on kirjutatud ka tehnikateadlastest, Tallinna Tehnikaülikoolist ja sealt võrsunud asutustest (nt küberneetikainstituudist). ${ }^{65}$ Parimatel juhtudel, nagu eespool mainitud Balti traditsioon, on Eesti teadusajaloo kaudu panustatud ka laiematesse debattidesse (nt evolutsiooniteooria retseptsioonist), ent samas on need uurimused jäänud eelkõige internalistlikuks, keskendudes distsipliinisisese arengu skitseerimisele laiema ühiskondliku konteksti arvelt.

Sellegipoolest võib just teadusajaloolistes uurimustes tabada analüütiliselt keerukamat vaatenurka rahvusriigile kui ajaloolise uurimuse vaikekonteinerile. Nii näiteks kirjeldavad Marek Tamm ja Kalevi Kull artiklis „Eesti teooria“ Karl Ernst von

${ }^{63}$ Kalling, K., Tammiksaar, E. Descent versus Extinction: The reception of Darwinism in Estonia. - The reception of Charles Darwin in Europe. Ed. by E.-M. Engels, T. F. Glick. Continuum, London, 2008, 217-229; Undusk, J. Das baltische Pantheon in der Naturphilosophie: Baer, Uexküll, Ostwald und das Problem der Zeit. - Umweltphilosophie und Landschaftsdenken im baltischen Kulturraum: Environmental Philosophy and Landscape Thinking. Hrsg. v. L. Lukas, U. Plath, K. Tüür. (Collegium litterarum, 24.) Underi ja Tuglase Kirjanduskeskus, Tallinn, 2011, 112-136.

${ }^{64}$ Tohvri, E. Georges Frédéric Parrot: Tartu Keiserliku Ülikooli esimene rektor. Tartu Ülikooli Kirjastus, Tartu, 2019.

${ }^{65}$ Pullat, R. Danzigi Tehnikaülikool Eesti tehnikaharitlaskonna kujunemisloos 1904-1939. Estopol, Tallinn, 2015; Tallinna Tehnikaülikool 1918-2018. Toim T. Liibek, L. Suurmaa. TTÜ Kirjastus, Tallinn, 2018; Pullat, R., Liibek, T. Oma alma mater'it otsimas: Enne Teist maailmasõda Euroopa tehnikakõrgkoolides võsunud insenerid ja arhitektid. Estopol, Tallinn, 2020; Küberneetikainstituut muutuvas ajas. Toim M. Kutser. TTÜ Kirjastus, Tallinn, 2000. 
Baerist Juri Lotmanini ulatuvat mõttetraditsiooni kui „maiskondlikku““ ${ }^{66}$ Ühelt poolt toovad nad esile selgete piirjoontega teooriatraditsiooni territorialiseerituse ühiste institutsioonide (mõisate, Tartu ülikooli), mõjuallikate, aga ka füüsilise keskkonna kaudu. Teisalt rõhutavad nad maiskondlikkuse tinglikkust, selle lahknevust riigi territooriumi piiridest ja selle mõjuallikaid saksa ratsionalismis ja romantismis. Võib küll polemiseerida artiklisse hõlmatud mõtlejate valikuprintsiipide üle, mis tunduvad liiga leebelt aktsepteerivat traditsioonilist baltisaksa eliidi ja näiteks ka mõisate rolli rõhutamist, siinkohal tahame aga rõhutada, kuidas see artikkel mõtestab produktiivselt ümber „Eesti“ kui raamistuse kasutamise ning arendab edasi maiskonna mõistet. „Eesti teoorias“ on uurimise all nii nähtuse sisu kui ka selle moodustumise tingimused, lisaks teooriale on küsimärgi alla seatud ka „Eesti““.

Omaette tasub välja tuua Juri Lotmanile ja Tartu-Moskva koolkonnale keskendunud uurimustööd, kus Lotmani mõtte arengut nähakse Nõukogude impeeriumi piiriala kontekstis ja kus keskseks küsimuseks on, Lotmani kaasuse näitel, piiriala rolli täpsem väljajoonistamine teadusajaloos.$^{67}$ Kuivõrd need uurimused rõhutavad sageli siinsete teadlaste holistlikku ja organitsistlikku orienteeritust, võiksid need kõnetada viljakalt mõttelugusid, mis seostavad keskkonnateadusi etniliselt ja poliitiliselt, aga ka klimaatiliselt pluralistlike piirkondadega, nagu on teinud seda Deborah Coen monograafias kliimauuringute sünnist Austria-Ungari keisririigis. ${ }^{68}$

Poliitiliselt tundlikumat ainest võib leida Ken Kallingu meditsiiniajaloolistest uurimustest, mis on keskendunud sõdadevahelise Eesti karskusliikumisele ja „tõutervishoiule" ehk teisisõnu eugeenikateadustele. Kalling seob vaikiva ajastu eugeenilise ideoloogia, teaduse (eugeenikaloengud ja 1938. aastast ka eugeenikainstituut Tartu ülikoolis) ja seadusandluse (1936. aasta steriliseerimisseaduse) karskusliikumise pikema ajalooga. Selmet jätta eugeenika autoritaarse riigikorra eripäraks ja seega omamoodi erandiks, näitab Kalling tõutervishoiu seotust rahvusliku liikumise ja eriti rahvusliku eliidi ideedega juba sajandivahetusel, kui loodusteaduslike tõuteooriate mõjul ja eeskätt just haritud eliidi (Jaan Tõnissoni, Villem Reimani) eestvedamisel hakkas eesti rahvuskäsitlus biologiseeruma. ${ }^{69}$ Rassimõtte kesksust Eesti rahvusliikumises 19. sajandi lõpul ja 20. sajandi alguses on käsitlenud ka kunstiaja-

${ }^{66}$ Tamm, M., Kull, K. Eesti teooria, 584. Vt ka Tamm, M., Kull, K. Toward a reterritorialization of cultural theory: Estonian theory from Baer via Uexküll to Lotman. - History of the Human Sciences, 2016, 29, 1, 75-98.

${ }^{67}$ Waldstein, M. The Soviet empire of signs: A history of the Tartu school of semiotics. VDM Verlag, Düsseldorf, 2008. Beecher, D. I. Ivory tower of Babel: Tartu University and the languages of two empires, a nation-state, and the Soviet Union. PhD Dissertation. University of California - Berkeley, Berkeley, 2014. Trunin, M., Pilshchikov, I. The Tartu-Moscow school of semiotics: A transnational perspective - Sign Systems Studies, 2016, 44, 3, 368-401.

${ }^{68}$ Coen, D. Climate in motion: Science, empire, and the problem of scale. University of Chicago Press, Chicago, 2019.

${ }^{69}$ Kalling K. Karskustöö sünnitab eugeenikaliikumise - Mäetagused, 2007, 36, 59-78, Kalling, K. Application of eugenics in Estonia 1918-1940. - Baltic Eugenics: Bio-Politics, race and nation in interwar Estonia, Latvia and Lithuania. Ed. by B. Felder, P. Weindling. Rodopi, Amsterdam, 2013, 49-82. Kalling, K., Tammiksaar, E. The politization of the temperance movement in pre-independence Estonia. - Explorations in Baltic medical history, 1850-2015. Ed. by N. Hansson, J. Wistrand. Rochester: University of Rochester Press, Rochester, 2019, 113-131. 
loolane Bart Pushaw, kes on näidanud, kuidas Eesti visuaalkultuuri konstrueerivate kunstnike soov näidata eestlaste kuulumist „tsiviliseeritud“ rasside hulka oli rahvusliku eneseloome üks keskseid osi. ${ }^{70}$ Need uurimused seovad ühte narratiivi teadusajaloo, visuaalkultuuri ajaloo, Eesti poliitilise ajaloo ja sotsiaalajaloo, näidates rassilise eristamise ja eestlaste rassilise kuuluvuse küsimuse olulisust Eesti kõrgkultuuri eri valdkondades ja sidudes need rahvusluse ajalooga laiemalt.

Viimase suurema liinina esineb teadusajaloos inseneriteaduste ja tööstuse ajalugu, rõhuga põlevkivil. Siin on ühelt poolt suur potentsiaal rahvusülesteks ja sotsiaalajaloolisteks uurimusteks, kuivõrd põlevkivikaevandamise ja sellega seotud inseneriteaduste areng on vääramatult seotud Saksa ja Nõukogude okupatsiooni, sõjatööstuse, migratsiooniprotsesside, plaanimajanduse ja muu sellisega. Reaalsuses on need valdkonnad jäänud üksteisest eraldatuks: majandusajaloolised ülevaated Eesti industrialiseerimisest nõukogude perioodil ${ }^{71}$ seisavad eraldi kultuurigeograafilistest vaatlustest põlevkivibasseinide rollist Ida-Virumaa maastikul ${ }^{72}$ ning teadusajaloolistest uurimustest põlevkivikaevandamise ekspertiisi tekkimisest Vene impeeriumi lõpuaastatel. ${ }^{73}$ Samuti on üldjoontes tegemist internalistlike analüüsidega. See on kummastav, arvestades kuivõrd on energeetikaajaloolistes uurimustes keskkonnakriisist lähtuvalt rõhutatud erinevate toorainete kasutuselevõtu taga seisvaid poliitilisi kaalutlusi ning toorainete, nende töötlemismeetodite ja teadusekspertiisi mõju nii ühiskondlikule võimusuhete jaotusele kui ka keskkonnale. ${ }^{74}$

\section{KESKKONNAAJALUGU}

Ka keskkonnaajaloo puhul rõhutavad uurijad oma valdkonnasisestes ülevaadetes algupäraste uurimuste nappust. ${ }^{75}$ Viimasel kümnendil on põhirõhk läinud valdkonna institutsioonide ülesehitamisele, klassikaliste meetodite tutvustamisele ja regiooni spetsialistide võrgustike tekitamisele konverentside ja piirkondlike ühenduste loomise kaudu. Olemasolevad keskkonnaajaloolised projektid sobituvad ühtaegu Eestis pikema traditsiooniga argiajaloo žanrisse - näiteks on põhjalikult uuritud Eesti toiduajalugu keskajal ja varauusajal - või siis mäluajaloo ja kultuurigeograafiaga seotud paikkonna- ja maastikuajaloo hulka. ${ }^{76}$ Kontseptuaalsed uuendused on vald-

${ }^{70}$ Pushaw. B. The global invention of art: Race and visual sovereignty in the colonial Baltic world, 1860-1920. PhD Dissertation. University of Maryland, College Park, 2019.

${ }^{71}$ Mertelsmann, O. The economic impact of the early Cold War on the Estonian SSR. - Behind the Iron Curtain: Soviet Estonia in the era of the Cold War. Ed. by T. Tannberg. Peter Lang, Frankfurt, 2015, 119-137.

${ }^{72}$ Printsmann, A. Maastiku amneesia: Põlevkivimaa rekultiveerimine. - Maastik ja mälu: Pärandiloome arengujooni Eestis. Toim L. Kaljundi, H. Sooväli-Sepping. Tallinn, Tallinna Ülikooli Kirjastus, 2014, 365-398.

${ }^{73}$ Tammiksaar, E. Põlevkivitööstuse algus Eestis - eeldused ja põhjused: Ajalooline sissevaade I-II. - Akadeemia, 2013, 1, 15-48; 2, 278-310.

${ }^{74}$ Mitchell, T. Carbon democracy: Political power in the age of oil. Verso, New York, 2011.

${ }^{75}$ Tüür, K. The Estonian environmental history scene.

${ }^{76}$ Põltsam-Jürjo, I. Viin, vein ja vesi: Joogikultuur Eestis kesk- ja varauusajal. Argo, Tallinn, 2020; Food culture and politics in the Baltic states. Ed. by D. Mincyte, U. Plath. Journal of Baltic Studies, 
konda tulnud ühelt poolt keskkonnaajaloo keskuse rahvusvaheliselt lõimitud tegevuse ja probleemipüstituste kaudu ning teiselt poolt külgnevatest distsipliinidest. Ökokriitilise vaatenurga näol on seda mõjutanud eeskätt biosemiootika ja kirjandusteadus, mis on käsitlenud looduse representeerimist tekstides ning inimeste ja mitteinimeste vahelist suhtlust, sageli ajaloolist materjali kasutades. Nendes kõrvaldistsipliinides tehtud, ajaloolisele ainesele tuginev töö on tunnistuseks ühelt poolt uurimisala interdistsiplinaarsusest ja teisalt sellest, kuivõrd Eesti kohalik mõttelugu on kujundanud siinse keskkonnaajaloo uurimisküsimusi. Samas on veel algusjärgus olevate projektide puhul näha selget haakumist keskkonnakriisi ja selle poliitikaga, peegeldades nii rahvusvahelisi trende. ${ }^{77}$

Biosemiootika on eluslooduses toimivaid märgisüsteeme analüüsiv teadus, mis rõhutab keemilis-füüsikaliste protsesside (nt organismi homöostaasi või immuunsüsteemi reaktsioonide) seotust märgisüsteemide ja nende tõlgendustega (nt organismi ohustavate bakterite või viiruste äratundmine, aga ka vaktsiinide tööpõhimõtteks olev immuunsüsteemi ,petmine“). ${ }^{78}$ Nagu keskkonnaajaloolased, ei erista ka biosemiootikud inimtekkelisi märgisüsteeme ja mitteinimestest loomade märgisüsteeme, vaid rõhutavad nende vastasmõju ja hübriidsust. See on viinud huvitavate ajaloouurimusteni, kus rõhutatakse kultuuriliste representatsioonide sõltumist muutuvast keskkonnast, näiteks võõrliikide mõiste ja konnotatsioonide muutumist 20. sajandi teise poole linnaruumis või loomaaedade tähendusvälja muutumise mõju seal elutsevatele loomadele. ${ }^{79}$

Empiirilistest uurimustest olulisemgi on biosemiootika roll keskkonnaajaloolaste jaoks uute kasulike analüütiliste tööriistade arendamisel. Kalevi Kull on arendanud ja süstematiseerinud biosemiootika põhimõtteid ja sõnavara, millest paljud „omailm“, „tõlkimisprotsess“, „,semiootiline lävi“ - on võetud kasutusele ka keskkonnahumanitaarias, sh ajaloolisele materjalile tuginevates töödes ${ }^{80}$ Kadri Tüür ja Timo Maran on tegelenud põhjalikult „tõlkimistööga“, näidates, kuidas biosemiootika tööriistu on võimalik rakendada kirjandusanalüüsis. ${ }^{81}$ Just kirjandusanalüüsis ongi Eesti keskkonnahumanitaaria kõige enam kanda kinnitanud ning sealt lähtuvad

2015, 46, 3 (ajakirja erinumber); Põltsam-Jürjo, I. Söömine ja joomine keskaegses Tallinnas. Argo, Tallinn, 2012; Raudkivi, P. Maa meie ema, ilm meie isa: Märkmeid looduse rollist Liivimaa 14. sajandi ajaloos. - Acta Historica Tallinnensia, 2010, 15, 3-23. Mänd, A. Beaver tails and roasted herring heads: Fast as feast in late-medieval Livonia. - Medium Aevum Quotidianum 50. Ed. by G. Jaritz. Gesellschaft zur Erforschung der Materiellen Kultur des Mittelalters, Krems, 2004, 5-12

77 „Eesti keskkonnaliikumine 20. sajandil: ideoloogia, diskursid, praktikad“ (projekti juht U. Plath), Tallinna Ülikool, 2020-2024.

${ }^{78}$ Kull, K. Biosemiootika. - Keel ja Kirjandus, 2008, 51, 8-9, 665-674.

${ }^{79}$ Magnus, R., Remm, T. Eesti võorliikide tähendusväli: kujunemine ja linnaruumi kontekst - Acta Semiotica Estica, 2018, 15, 89-118; Mäekivi, N., Maran, T. Semiotic dimensions of human attitudes towards other animals: A case of zoological gardens. - Sign Systems Studies, 2016, 44, 1/2, 209-230.

${ }^{80}$ Kull, K. Biosemiootika.

${ }^{81}$ Maran, T. Biosemiotic criticism: Modelling the environment in literature. - Green Letters: Studies in Ecocriticism, 2014, 18, 3, 297-311; Tüür, K. Bird sounds in nature writing: Human perspective on animal communication. - Sign Systems Studies, 2009, 37, 3/4, 226-255. 
küsimused tõlgenduslikkusest, agentsusest ja representatsioonist on kandunud edasi ka teistesse valdkondadesse. ${ }^{82}$

Siit jõuame teise Eesti keskkonnaajalugu mõjutanud mõttevoolu juurde, milleks on ökokriitika. Ökokriitika analüüsib looduse kujutamist kirjanduses ja looduse mõju tekstilistele representatsioonidele, pöörates erilist tähelepanu inimese ja looduse vahel tõmmatavatele piiridele, implitsiitsetele hierarhiatele ja alistamissuhetele. ${ }^{83}$ Ingliskeelses teadusmaailmas on ökokriitika selgelt kriitilise iseloomuga selle eesmärk on avada varjatud võimusuhteid, mida põlistab inimese ja looduse vastandamine, ning astuda samas taktis keskkonnakaitse liikumisega, mille mõjul see mõttevool 1970. aastatel tekkis. Eestis on ökokriitika tihedamini seotud biosemiootikaga ning selle keskmes on inimeste ja mitteinimeste märgisüsteemide omavahelise tõlkimise protsess. ${ }^{84}$ Muidugi on ka ühiseid rõhuasetusi: looduskeskkonna mõju selle representeerimisele, teisalt samas looduskirjanduse mõju loodusega suhestumisele. Eripärana tegeletakse Eesti ökokriitikas rohkem mitteinimeste tähendussüsteemide (nt linnulaulu) kirjeldamise ja analü̈̈siga ning uuritakse mehhanisme, mille abil toimub (või ei toimu) eri liikide vaheline kommunikatsioon. ${ }^{85}$

Keskkonnaajaloolistes uurimustes on ökokriitika ja biosemiootika mõju väljendunud koha- ja maastikuajaloolistes töödes, mis uurivad näiteks Baltimaade mõisakeskkonna mõju siinsele loodusfilosoofiale. Biosemiootika jälge on tunda mõistestikus (eriti keskne on Uexkülli omailm - Umwelt) ning mitteinimeste ja keskkonna loodusteadusliku analüüsi kaudu, ökokriitika mõju ilmneb jällegi kirjanduslike ja kunstiliste allikate olulisuse kaudu. ${ }^{86}$

Nende meetodite abil on üritatud ületada või täiendada ingliskeelseid ökokriitika analüüse, mis Kadri Tüüri sedastusel keskenduvad suuresti looduse kujutamise ideoloogiate selgitamisele. ${ }^{87}$ Siiski võiks just kultuuriteadustest sammukese sotsiaal- ja majandusajaloo poole astumine anda ühe viljaka võimaluse keskkonnaajaloo tööpõllu laiendamiseks ja tihedamaks sidumiseks ökoloogilise kriisi problemaatikaga, mis mõjutab aina rohkem ajaloolaste uurimisteemasid kõikjal maailmas. Sammukesi selles suunas on ka tehtud, näiteks Kadri Tüüri ja Karl Sterni ühises uurimuses Atlandi heeringa majanduslikust ja ideoloogilisest rollist, ent see jääb siiski kirjandusanalüüsi ja majandusajaloo ristumiskohta, keskkonna ja majanduse seost põhjalikumalt vaatlemata. ${ }^{88}$ Viise lõimida tihedamalt kultuuriliste representatsioonide ja diskursuste ning ühiskonna ja majanduse analüüsimist on viimasel ajal

${ }^{82}$ Eesti looduskultuur. Toim T. Maran, K. Tüür. Eesti Kirjandusmuuseum, Tartu, 2005.

${ }^{83}$ Cronon W. Uncommon ground: Rethinking the human place in nature. W. W. Norton, New York, 1996.

${ }^{84}$ Tüür, K. Semiotics of nature representations: On the example of nature writing. PhD Dissertation. University of Tartu, Tartu, 2017.

${ }^{85}$ Magnus, R. The Semiotic grounds of animal assistance: Sign use of guide dogs and their visually impaired handlers. PhD Dissertation. University of Tartu, Tartu, 2015.

${ }^{86}$ Maastik ja mälu: Pärandiloome arengujooni Eestis; Umweltphilosophie und Naturdenken im baltischen Kultuurraum.

${ }^{87}$ Tüür, K. Bird Sounds in Nature Writing, 252.

${ }^{88}$ Tüür, K., Stern, K. Atlantic herring in Estonia: In the transverse waves of international economy and national ideology. - Journal of Baltic Studies, 2015, 46, 3, 393-408. 
otsitud ka loomaajaloo seminaride raames, mis on kokku toonud zoosemiootika, ökokriitika ja keskkonnaajaloo uurimistraditsiooni. ${ }^{89}$

Materiaalsemat käsitlusviisi keskkonnaajaloole esindavad kliimaajaloolised uurimistööd, mis vaatlevad nii Eesti kliima variatiivsust pikas perspektiivis kui ka äkiliste kliimamuutuste mõju saagikusele, haigustele ja suremusele konkreetsetel perioodidel.${ }^{90}$ Nii on Priit Raudkivi näidanud, kuidas 1783. aastal toimunud Laki vulkaanipurse Islandil võis suurendada suremust Eestis ja soodustada sääskedega kantavate nakkushaiguste levikut, samuti on ta uurinud 19. sajandi alguses Eestit tabanud näljahäda ja suremuse võimalikku seost muutuvate ilmastikuoludega, nii nagu seda on täheldatud Põhja-Läti puhul. ${ }^{91}$ Selliste materiaalsetele muutustele keskenduvate uuringute ühendamine representatsioonide ja võimusuhete analüüsiga võiks anda alust tõeliselt murrangulisteks ajalookäsitlusteks.

Pakume välja ka ühe võimaluse niisuguseks uurimistööks. Eelnevas teadusajaloo ülevaates mainitud küsimused Eesti insener-tehnilise mõtte kujunemisloost, põlevkivikaevandamise sünnist ja arengust eri riigikordade ajal ning fossiilkütustel põhineva energiataristu kujunemisest võidaks just keskkonnaajaloolisest lähenemisviisist. Sel moel võiks vaadelda näiteks vastuolusid Eesti rahvusliku loodusmõtte ja erakordselt saastava modernse taristuloome vahel, uurida, millistel aegadel on need kaks traditsiooni omavahel suhestunud, olgu antagonistlikult või dialoogiliselt, ja kuidas, milliste retooriliste ja materiaalsete strateegiatega on neid lahus hoitud ja tööstusmajanduse mõju loodusele hägustatud. ${ }^{92}$ See vajaks ühelt poolt tugevale empiirikale tuginevat tehnoloogia- ja meditsiiniajalugu, mis vaatleks tööstusühiskonna ehitamise tagajärgi inimeste ja looduse heaolule, kutsehaiguste, hingamisteede haiguste jm levikule, teisalt jällegi tugevat poliitilist ja ökokriitilist analüüsi, mis vaatleks, kuidas neid töötusliku modernsuse tagajärgi diskursiivselt esitati ja Eesti loodusmõtte arenguga sobitati. Kuigi esimesi samme selles suunas tehakse, on Eesti tööstusliku modernsuse keskkonnaajalooline analüüs praegu sisuliselt olematu. ${ }^{93}$

\section{KOKKUVÕTTEKS}

Eeltoodust võib teha mõned praktilisemat laadi ja mõned veidi suuremad üldistused. Esmalt vajavad peaaegu kõik kirjeldatud suundumused seda, et uusi visioone välja pakkuvad teadlased jõuaksid teha laiapõhjalist uurimistööd. Samuti paistab hästi

${ }^{89}$ Entangled human-animal histories: Practices and imaginaries from the eastern Baltic borderlands. Ed. by L. Kaljundi, A. Mänd, U. Plath, K. Tüür, K. Peter Lang. Berlin (ilmumas).

${ }^{90}$ Eesti kliima minevikus ja tänapäeval. Toim J. Jaagus, A. Kallis, A. Tarand. Tartu Ülikooli Kirjastus, Tartu, 2016.

${ }^{91}$ Raudkivi, P. Islandi 1783. aasta vulkaanipurske võimalikust mõjust Eestis: Keskkonnaajalooline arutlus. - Acta Historica Tallinnensia, 2014, 20, 1, 51-73; Raudkivi P. Ilm teeb ajalugu: Aspekte talurahva ühiskondlikust haavatavusest Eesti- ja Liivimaal 19. sajandi algul - Acta Historica Tallinnensia, 2016, 22, 18-40.

92 Kaljundi, L. Uusmetsik Eesti - Vikerkaar, 2018, 7/8, 68-80.

93 „Eesti energia-, transpordi- ja telekommunikatsioonisüsteemide ümberkujundamine Teise Suure Siirde lävel“" (projekti juht M. Keller), Tartu Ülikool, 2019-2023. 
välja kultuurilise pöörde mõju, kuna ka ajaloo uurimist on palju edasi viinud kirjanduslike ja teiste kultuuritekstide uurimine. Selle kõrval on suhteliselt vähem analüüsitud diskursuste seoseid ühiskondlike võimusuhetega. Jääb loota, et neid seoseid jõutakse edaspidi rohkem uurida ning et selle kõrval kujuneb ulatuslikumaks ka materiaalse ja keskkonnahumanitaarse pöörde mõju. Nagu öeldud, võiksid olla iseäranis huvitavad sellised uurimused, mis analüüsiksid diskursuste või lihtsalt kultuuriliste representatsioonide kõrval ka materiaalset ja mitteinimlikku, sealhulgas keskkonda. Siin näeme potentsiaali Unduski, Tamme, Kulli jt tekstides välja töötatud maiskondlikkuse ideel, mis haakub keskkonnahumanitaarias keskse orgaanilise ja ökoloogilise mõtlemisega, reifitseerimata samal ajal piirkondlikke identiteete defineerivaid kategooriaid (nagu näiteks rahvus). Maiskondlikkus aitab rõhutada ühes kultuurilisi ja keskkondlikke perekonnasarnasusi jagavas piirkonnas tegutsevate inimeste ja mitteinimeste omavahelist, tahtest sõltumatut seostust, andes samas aru, et nende sidemete ja vastasmõjude kõrval (olgu selleks ühine keskkonnaruum, arusaamine kultuurilistest-ajaloolistest kihistustest või midagi kolmandat) mängivad rolli ka teised, rahvusülesed sidemed (nt kirjavahetus Euroopa või Venemaa teadlastega, ookeaniülene kaubavahetus jm). Samuti väldib see selliste mõistete nagu ,,rahvus“, ,kultuur“, ,paikkondlik identiteet" kivistumist ja tunnistab neid lihtsalt kui territorialiseeritud kategooriaid, mille ajalooline kujunemislugu on sattumuslik, mitte ettemääratud, ning mis seetõttu vajavad analüüsi ja seletamist.

Eestil on head eeldused olla sedalaadi uurimistööga seoses huvipakkuv ka laiemas plaanis. Erinevate režiimide vahetumine ja kultuurimõjud on toonud kaasa suhteliselt kiire ideede ja praktikate ülevõtmise, põimumise ja adapteerimise - ning väike piirkond ja kultuuriruum võimaldavad neid protsesse, muutusi ja hübridiseerumist suhteliselt hästi analüüsida. See on tähtis ka kohalikus plaanis. Eesti uuem ajalookäsitlus keskendub suuresti rahvusliku ajaloo tavapärastele uurimisalustele (eesti keskklass, haritlased, talurahvas), jättes välja mitmed teised ühiskondlikud ja etnilised rühmad. Isegi juhul, kui seda tehakse rahvusliku diskursuse dekonstrueerimise eesmärgil, marginaliseerib see ikkagi alternatiivsed ajaloo subjektid. See pole oluline mitte lihtsalt „unustatud häälte esiletoomise seisukohalt", vaid seetõttu, et marginaliseerimine taastoodab iseennast: lihtne on väita, et naised või töölised olid ühe või teise ajaloolise arengu seisukohalt marginaalsed, kui nende rolli pole kunagi uuritudki. Ajalookirjutuse subjektide valik on iseenesest poliitiline, ajaloolased ei saa neis küsimustes esitleda end „kõnelejatena kõrgemalt“. Siin võiks kasu olla ka huvist võimu ajaloo vastu nii selle diskursiivsetes kui ka veelgi otsesemalt ühiskondlikes avaldumisvormides: millised on võimu teostamise mehhanismid, millised on nende tagajärjed rühmadevaheliste võimusuhete ümberjaotamise seisukohalt (langemata siinjuures tavapärastesse dihhotoomiatesse omad/võõrad, põlisrahvas/vallutajad).

Oma rolli võib siinjuures mängida ka arusaam ajalooteaduse enese poliitilisest rollist. Kui Eestis valitseb siiani pigem ajalooteaduse objektiivsuse ideaal, siis mitmed eespool välja toodud, ajalooteaduses esile kerkinud uued suunad on sündinud tihedas dialoogis ühiskondliku ja poliitilise olukorraga ning kantud soovist kaasa rääkida ja teadus elevandiluust tornist välja tuua - ajaloolaste rolli Rancière'i „tajutava jaotuskorra" kehtestamisel ei ole lihtsalt olnud võimalik eirata. Post-nõukogude 
ühiskondades ei ole neid ideid nii kergesti omaks võetud, aga siin ei ole toimunud ka selliseid teadlasi põhjalikult kaasavaid debatte nagu näiteks 1980. aastate Historikerstreit Saksamaal või mälusõjad Prantsusmaal. Raske on ka näha, et arusaam ajaloo rollist võiks muutuda ilma ajaloolaste aktiivsema osaluseta avalikes aruteludes, tunnistades, et uurimisteemade ja -raamistike valikul on distsipliinisisestest vaidlustest laiemad järelmid.

\title{
TÄNUAVALDUS
}

Artikli valmimist on toetanud Eesti Teadusagentuuri grandid PRG346 „Eesti energia-, transpordi- ja telekommunikatsioonisüsteemide ümberkujundamine Teise Suure Siirde lävel“ ning PRG908 „Eesti keskkonnaliikumine 20. sajandil: ideoloogia, diskursid, praktikad“.

\section{NEW DEVELOPMENTS IN ESTONIAN HISTORICAL RE- SEARCH IN THE TWENTY-FIRST CENTURY}

\author{
Linda KALJUNDI and Aro VELMET
}

This article provides an overview of new research trends in the study of Estonian history in the twenty-first century. The paper focuses on the emergence of transnational history, memory studies, the history of science and environmental history. We argue that these research fields have brought into focus previously marginalised social groups and agents, and highlighted the political nature of any kind of historical scholarship. Research carried out in these new frameworks has also helped to challenge methodological nationalism, pointing to the role of non-Estonian actors in the history of the country, and to the entanglement of Estonian history with other regions. The paper is not limited to historical research in the traditional sense, but takes a more pluralist approach, covering also the developments in other humanities that utilise historical sources. We argue that a considerable amount of new innovative historical research is done in adjacent disciplines, such as semiotics, literature studies, and ethnology.

While historians have developed transnational history by studying the history of the Baltic provinces in the multi-ethnic Russian empire, literary scholars have discussed the ways in which early modern and modern Baltic history can be approached from entangled perspectives. In recent years, those scholars have argued for the primacy of colonialism as a central concept for the understanding of Estonian and Baltic history. The concept has been used widely in studies of medieval colonisation, as well as in connection to the complex and tenuous colonial relations between Baltic Germans and Estonians. Nevertheless, a colonial history of Estonia would benefit greatly from broader discussions on the adaptability of the term and its related concepts for different time periods and contexts of the region's history. 
So far, debates on colonialism have focused on the possibilities of analysing the Soviet regime as a form of colonialism, once again driven primarily by literary scholars. Interdisciplinary dialogues have also been central to memory studies, which has resulted in some of the most substantial and prolific scholarship in recent years. While much of that research has focused on analysing national sites of memory, other scholars, particularly ethnologists, have pointed to the conservative nature of Estonian memory politics and highlighted counter-memories and marginalised voices otherwise obscured in collective memory. Estonian environmental history is likewise strongly influenced by other disciplines in the humanities, especially ecocriticism and eco-semiotics, both of which have long traditions in local scholarship. The development of the field could yet benefit from stronger connections between the histories of technology, economy and society, on the one hand, and the analysis of cultural imaginaries, on the other hand. In sum, the developments described above have all emphasised the study of cultural representations. All the aforementioned fields would benefit greatly from entangling the studies of cultural imaginaries with the studies of social and economic history, and from a stronger emphasis on the analysis of power relations. 